\title{
Store medisinske spørsmål
}

Du står fast på noe medisinsk og tyr til Google. Et av de øverste treffene er en artikkel fra Store norske leksikon. Men kan du som lege stole på det du leser der?

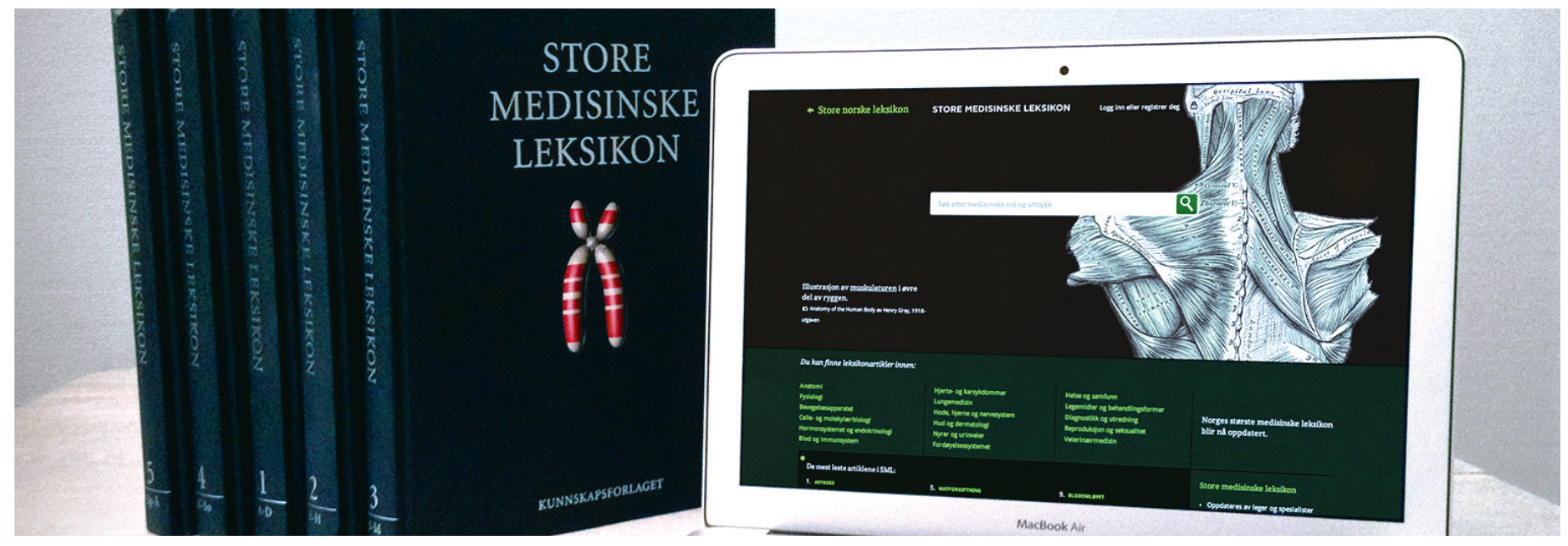

Store medisinske leksikon ble integrert i Store norske leksikon - www.snl.no - i 2013. Foto: Erik Dyrhaug

Når du søker på noe medisinsk i Store norske leksikon (www.snl.no), kommer du automatisk videre til Store medisinske leksikon (SML). Det ble utgitt i fem bind i 2006-07 og inneholdt nær 14000 artikler. Målgruppen var helsepersonell og pasienter.

- Fra vi relanserte verket i 2013 og slo det sammen med det medisinske stoffet i Store norske leksikon, har mesteparten av jobben foregått sentralt i redaksjonen, med rydding i dubletter, organisering av fagområder og jobbing med konsept. Rekrutteringen av nye fagansvarlige har begynt, men det faglige oppdateringsarbeidet er fortsatt bare i startgropen, sier utviklingsleder og redaktør Georg Kjøll til Tidsskriftet.

Innen feltet medisin er det 26 fagansvarlige. Flesteparten av disse var også fagansvarlige for papirutgaven av Store medisinske leksikon i 2007. For å bli fagansvarlig kreves det solid bakgrunn fra området man skal ha ansvar for og erfaring fra både klinisk arbeid og forskning.

\section{Lang erfaring som fagansvarlig}

Professor Britt-Ingjerd Nesheim ved Universitetet i Oslo har vært fagansvarlig i over ti år. Hun har skrevet 222 leksikonartikler og vært fagkonsulent for 11 - alle innen feltet gynekologiske sykdommer, reproduktiv helse, svangerskap og fødsel.

- Jeg overtok i sin tid ansvaret for artikler som andre hadde skrevet, men skriver også nye. Det jeg først og fremst driver med, er å oppdatere allerede eksisterende artikler. Det er et enormt arbeid, men morsomt. Alle som bruker Store norske leksikon kan foreslå endringer, og så er det opp til oss fagansvarlige å godta eller forkaste forslagene. Men det er svært få som kommer med tilbakemelding, så det meste av oppdateringen skjer på vårt initiativ, sier Nesheim.

\section{Mye å oppdatere}

Thale Kristin Olsen er lege, doktorgradsstipendiat ved Universitetet i Oslo og redaksjonsmedarbeider innen medisin i Store norske leksikon. Hun svarer på kommentarer og spørsmål fra brukerne, driver faktasjekking, oppdaterer artikler og bistår redaksjonen. Hun mener leger helt klart kan stole på det de leser i Store norske leksikon og Store medisinske leksikon.

- Stoffet er skrevet av dyktige fagansvarlige leger og forskere og er sånn sett medisinskfaglig kvalitetssikret. Men det er så klart mye å oppdatere, siden medisinen hele tiden er i utvikling. Vi oppdaterer artikler om legemidler som ikke lenger er i bruk, om behandling som er endret og om dagsaktuelle temaer. I høst har jeg for eksempel oppdatert artikkelen vår om ebola, sier Olsen.

Britt-Ingjerd Nesheim bruker ikke selv Store norske leksikon når hun lurer på noe medisinskfaglig.

- Nei, jeg slår ikke opp der da, altså. Da går jeg til andre kilder. Innholdet er jo ikke beregnet på fagfolk, men på folk flest, sier Nesheim.

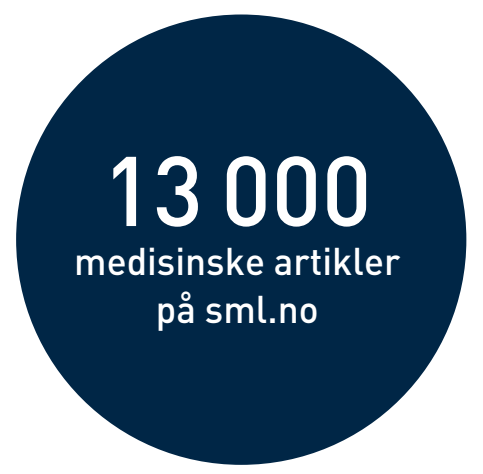

